\title{
Tourism Promotion of Destination for Swedish Emissive Market
}

\author{
Neven Šerić, Filipa Marušić* \\ Faculty of Economics, University of Split, Croatia
}

Copyright $\subseteq 2019$ by authors, all rights reserved. Authors agree that this article remains permanently open access under the terms of the Creative Commons Attribution License 4.0 International License

\begin{abstract}
Marketing tools in tourism are constantly changing. The competition in the global tourism market is exponentially growing. Common practice in the tourism sector is the promotion of destination offer to send target audience specific image in correlation with extra destination value. Customizing destination promotional mix to fit global touristic standards ensures efficient destination positioning but includes higher investment. Management of integral parts of the promotional mix is defined with undifferentiated supply and the general image of destination as well as completely opposite terms of the differentiated offer and the general image of the destination. Most of the tourism-related organizations adjust its promotional mix according to values and image they want to present to the target audience. In the same time, there aren't many tourism organizations, which adjust its promotional mix to different emissive markets. The main research question of this paper is "Does the strategic commitment of a receptive destination offer in terms of managing the marketing mix present strength or weakness?" The paper will present research results from the survey conducted on tourists from Swedish emissive market in order to define recommendable outlines for the successful promotion of tourism services on the selected emissive market. Given the fact the authors of this paper conducted two parallel primary types of research of attitudes among different samples of the same emissive market (one of them were Swedish tourists who didn't visit Croatia). Linking of these two aspects has been a research challenge to the expected contribution in the sphere of realizing advisable guidelines for proactive management of destination promotion focused on one emissive market.
\end{abstract}

Keywords Tourism, Offer, Promotional, Managing, Sweden

\section{Introduction}

The main purpose of this paper is to research the potential of managing tourism promotion of the destination in order to achieve higher perceived value for Swedish emissive market. The research will show is it recommendable to use the specialization of tourism offer for Swedish specific emissive market. In managing tourism business in the destination, it is crucial to harmonize all promotional efforts to specific emissive market, especially activities related to managing promotional mix as Morrison [1] said. Choosing and defining the way of communication with targeted emissive market also has an important role in the process. In the context of research problem related to the recommendable approach to the strategic direction of tourism organization in terms of managing promotional mix, research has been conducted on sample of potential and previous visitors from Sweden and from a receptive business which already targets Swedish emissive market. Average tourist from Sweden is ready for higher extra expenditures, especially if expenditures are related to specific service and new experiences. Additional characteristics of Swedish tourist need for active holiday and interest for local customs and events. Hedlund, Marell, and Gärling [2] stated Swedish tourists are well known for their love for nature, but they are at same time introverted and have troubles blending in new surroundings as Prebensen, Skallerud and Chen [3] stated. On a sample of potential Swedish tourists, the efficiency of a strategic approach to target tourism promotion adjusted to emissive Swedish market is tested. Pike [4] said the process of managing promotional mix in tourism is specific due to the complexity of tourism services compared to the physical product. When it comes to Swedish emissive market it is interesting to note Croatia is getting more popular as the tourist destination as seen in different publications. Swedish tourists show interest in Croatia mostly because of nature, as well as cultural and historical heritage. Swedish emissive market shows a lot of similarities to other Scandinavian markets. The main reasons why Croatia is getting noticeable as destination is good ratio of investment and return, the attractiveness of heritage and nature, gastronomy and ease of reaching the destination by plane. These are qualities that attract other emissive markets to 
Croatia but what is interesting for Croatia as growing tourism destination is the fact the Swedish tourist is often loyal when it comes to choosing vacation destination and accommodation in destination. This means there is a potential to have growing number of loyal customers which will in enjoy in all Croatia has to offer. To Swedish guests when they choose accommodation the most important factors are location, food and drink, Wi-Fi access and fitness facilities which can be guidelines for available tourist resources and accommodation. For Croatia as a destination, trends in the recent period by Šerić, Jurišić [5] show an increase in growth of Scandinavian tourists, especially Swedish tourists. 88,3 percent of Scandinavian tourists heard of Croatia as a destination, while 68,5 percent know precisely where it is located. Most of the respondents want to visit Croatia in July and August, but there are significant percentage of those who want to visit Croatia during the spring and autumn period. On the online Scandinavian market, from 160 countries with tourism offer, Croatia is on 54th place in terms of interest. Croatia is on 32nd place related to visibility of online adverts, and when it comes to published media statements Croatia is on 18th place. When it comes to promotional material, Croatia is on 11th place and more than 92,1 percent of content is related to summer tourism offer. In accordance with the results of this research, it is recommended to develop alternative and specialized tourism products for yearlong offers.

\section{Theoretical Framework}

Development of destination promotion often follows already set tourism image and promotion has a crucial role in that process by Tribe [6]. Managing promotional mix should be defined as following: decide what to offer and to whom, price management, creating demand, destination availability, managing the income, leaving the good impression, the loyalty of guests, satisfaction measurement and evaluating performance according to Sharpley [7]. Suggested advice on how to manage the promotional mix of destination towards Raju [8] is:

- Implement breakeven point for every promotional activity and defining which investment to make, using contribution margin, not income;

- Make sure to have the consistent message with the basic positioning of destination - what plans and wants to offer to the targeted emissive market.

Moriarty, Mitchell and Wells [9] said communication is part of marketing action. Tourism promotion consists of advertisement, public relations, sales reinforcement, direct communication, events and sponsorships, sales places, digital media, communication aspects of packaging, as well as personal sales and new ways of communication. The main purpose of communication is that you can communicate all aspects of the promotional mix can send a certain message. Activities related to promotion are based on wide theoretical background. According to Candela and Figini [10], the main goals of promotional activities for the destination are informing, persuading and reminding. This means promotion stands for all activities related to informing, persuading and reminding with which receptive business stimulates sales or in this case growth of touristic visits to one receptive market. Some specific characteristics of managing promotional mix in tourism according to Butler [11], Raaij, Stoelhorst [12] and Sharpley [13] are:

- Pluralism of decision-making centers in marketing activity and need for integrated marketing and promotional mix;

- Tourism product is highly complex and has a great number of different elements;

- There are a lot of variables which are hard to control and most of them are external, mostly unknown factors;

- Some emissive markets have different variables which are part of the decision-making process in choosing tourism destination and they are often influenced by effective promotion, better means of travel and other variables;

- Marketing and promotional mix should be flexible;

- Characteristics of tourism demand, offer, sales and expenditures.

Having in mind all stated characteristics it can be concluded promotional mix in tourism is quite different from the promotional mix in other industries [1]. Media mix in most cases includes more than one media combined in order to achieve higher efficiency as stated in the book of Moriarty, Mitchell, and Wells [9]. One of the interesting researches is definitely one conducted on loyalty programs in Croatia in the paper of Šerić, Gil-Saura, Mollá-Descals [14]. It shows a significant bond between the perception of guest related to information technologies and integrated marketing communication and perceived IMC and loyalty to the brand. High level of implementation of ICT and IMC can increase loyalty to the brand of tourism product and ensure competitive advantage. It is necessary to have a holistic approach to marketing communication and with synergy achieve main influence through the main promotional message. Advertising in tourism needs to be adapted to the expectations of the target audience according to Conrady, Buck [15]. Every emissive market has its own way of perceiving image of destination presented on that market said Baxter, Kerr [16]. Advertising is more efficient on emissive markets with higher economic status and it transfers to informing role in creating demand for the brand according to Hall, Smith, Marciszewska [17]. It is advisable to create buzz and increase level of demand. Advertising of the destination ensures cost efficiencies marketing due to the fact it reaches wider groups of potential clients. Online communication canals are in relation to viral marketing and 
fast spreading of word of mouth. Word of mouth communication is efficient way of convincing potential guests in order to check recommendations. In case of emissive Swedish market, results of exploratory research shows the need to make stronger online communication with special emphasis on social networks. The business offering tourism services to Swedish customer should improve ways of the search for information, systems of online payment, availability of information, newsletters, on-line surveys when it comes to websites. Social networks are letting their users to create their own communities with connecting their personal websites. As addition to this range of websites users can join groups related to certain experience, opinion or mutual interests. Because of this it is recommendable to advertise Facebook or Instagram page of tourism organization in order to create their own user community where they can conduct different researches to find out how to adapt offer to guests' expectations. In this context viral marketing represents future of promotion said Middleton, Fyall, Morgan and Ranchhod [18]. On this platform it is needed to develop new marketing tools in order to strengthen brand image.

\section{Research}

\subsection{Research Hypothesis}

The hypotheses which will be tested in this paper are as follows:

H1: Swedish tourists do not perceive coastal Croatia as a desirable destination for the vacation;

H2: Existing tourism offer in coastal Croatia is not differentiated enough and inferiorly positioned on Swedish emissive market;

H3: Specialization in managing tourism promotion for emissive Swedish market does not contribute to the higher perceived value of the offer.

Some questions related to paper hypotheses are the following:

- How does Swedish emissive market perceive tourist offer of coastal Croatia?

- Are stated tourist resources attractive enough for Swedish emissive market?

- How to additionally improve tourist resources?

- How to adjust destination offer to Swedish emissive market?

- What is the influence of the price adjusted to emissive market for managing tourism offer?

- What is the influence of tourism promotion on managing the destination offer, and how to improve promotional mix?

- How to improve elements of tourism promotional mix for higher perceived value on Swedish emissive market?
- How to encourage Swedish tourists to visit Croatia more frequently?

\subsection{Characteristics of Swedish Emissive Market}

Characteristics of average Swedish tourist based on The Nordic Outbound Travel Market [19] are high average income, mobility throughout the year, more travels in one year, higher daily expenditures in the destination in relation to other nationalities, care about the environment, choosing of eco-friendly destinations and accommodation, search for unique experience, search for unexplored destinations, interest in meeting the hosts and local community, as well as learning local language, wish to adjust to local culture, accepting all cultures and differences, politeness and simplicity, showing interest for local cuisine, buying authentic products as souvenirs, wish for active and authentic vacation, giving generous tips, feeling safe in destination matters, grateful, values word of mouth, often shares its own word of mouth - has need to say praise for the destination to family, friends and business circles, wants to feel he got good value for money. Three main segments of Swedish tourists are families with children, singles with no children and empty nesters. 60 percent of this emissive market books their vacation online and through same online booking channels they do pre-research for vacation. The most relevant source of information as stated in research are people who have already visited the destination, Google.com, recommendation from friends and family, official pages of travel agencies, official pages of hotels and attractions. Although Sweden in comparison to other European countries has small population, in terms of expenditures it is on 8th place. By data collected from World Bank [20], Swedish tourist expenditures are in constant increase. Based on Market report - Focus on the EU and Swedish Market, Outbound Tourism [21], most visited winter destinations are countries with mild climate (Spain, Thailand, Egypt), while summer destinations are Greece, Turkey, Spain (hot summer), which shows that Swedes chose destinations with warmer climate than their own. People who travel the most are middle-aged singles without children (30\%), families with children (18\%), singles without children (19\%), children up to 17 years old (15\%), empty nesters $(9 \%)$, youth up to 24 years old $(9 \%)$. Variables that influence the choice of destination are: price of travel, climate of destination (61\%), natural attractions in destinations $(50 \%)$, gastronomic offer of the destination $(40 \%)$, cultural sites in destination (28\%), and shopping opportunities. Entertainment and activities in destination are also important factor for choosing proper destination (26\%). Other factors include positive exchange rate (15\%), low risk of catching a disease $(13 \%)$, low risk of natural catastrophes $(8 \%)$, low risk of being attacked by the animals (7\%). Trends on emissive Swedish market are as 
following as stated in Market report research [21]: recession recovery followed with more travels, growth of older population in tourist travels, search for unique experiences, interest in themed vacation, growing demand for all-inclusive packages, growing demand for combined travel, growing demand for city break travel, interest for green, eco-friendly destinations, more short trips through year, preferring destinations who advertise on Swedish language, coverage with fast internet connection. Tour operators from Sweden are interested in selling all-inclusive packages, which can be used as specialized for certain receptive markets, who can take over distribution channels. Swedish tourists often buy travel packages directly from Swedish tour operators and that is the reason more to connect with them for receptive tourist organizations. Their travel packages are relatively simple and standardized and usually offer flight and accommodation. They often cooperate with chosen tour operators on the receptive market. From local partners, they demand professionalism, unique experience, and offer. Therefore, local tour operators often have difficulties to offer something unique and make a profit. Besides main tour operators, Swedish touristic market is characterized by a big number of small tour operators, specialized tourist agencies and a few niche tour operators. Furthermore, there are few main chains of tourist agencies as well as a big number of online tourist agencies who sell short trips, excursions, plane tickets and other as stated in Market report research [21]. Due to the fact Internet is extremely important sales channel on the Swedish market it is clear that the promotional mix should develop in that direction.

\subsection{Findings of Conducted Primary Research}

Primary research in order to test set hypotheses is conducted with the survey among Swedish tourists. The intentional sample has been chosen on Swedish potential tourist market. Participants are all age groups, both genders, different educational and financial structure. Surveys are distributed via Google Docs and social network Facebook. The research was conducted during May/July 2017. With the first survey perception of Croatia as a destination on the emissive Swedish market has been tested as well as how the promotion via different communication channels contributes to the image of the receptive destination. The second survey tested the connection between choosing appropriate accommodation and image receptive destination. In addition, the half-structured interview was conducted with the expert in the field of collaborating with Swedish emissive market to get better insight in needs of the Swedish guest and what can be improved in promotional mix. The interview took place during September 2017. In the following text, the most important results of surveys are presented. The first survey was conducted on 50 potential visitors based on pre-test which showed interest in visiting Croatia. The second survey was conducted on 80 potential visitors chosen based on pre-test related to wider interest for tourist activities.

\section{Research Results}

Analysis of answers from both surveys, with use of descriptive statistics (Chi-square and Crosstabs in SPSS) showed most of the respondents (Swedish tourists) consider available tourist resources in Croatia as attractive. In following text conducted tests and the results will be presented. First table shows answers of respondents of different age groups on Likert scale from 1 to 5 the desirability of Croatia as tourist destination, where 1 stands for completely undesirable and 5 completely desirable. 25 respondents defined Croatia as partially desirable and 13 as completely desirable while 10 respondents replied Croatia is neither desirable nor undesirable. In same time just 4 respondents said Croatia is completely undesirable or partially undesirable.

Table 1. Desirability of Croatia as Touristic Destination According to Different Age Groups

\begin{tabular}{|c|c|c|c|c|c|c|}
\hline & \multicolumn{5}{|c|}{$\begin{array}{c}\text { On scale from } 1 \text { to } 5 \text {, how desirable is Croatia as } \\
\text { a tourist destination for you? }\end{array}$} & \multirow{2}{*}{ Tota } \\
\hline & 1 & 2 & 3 & 4 & 5 & \\
\hline $18-25$ & 1 & 1 & 8 & 13 & 8 & 31 \\
\hline $26-45$ & 0 & 2 & 1 & 8 & 2 & 13 \\
\hline $46-65$ & 0 & 0 & 1 & 4 & 1 & 6 \\
\hline 66 & 0 & 0 & 0 & 0 & 2 & 2 \\
\hline Total & 1 & 3 & 10 & 25 & 13 & 52 \\
\hline
\end{tabular}

Hypothesis H1 - Swedish tourists do not perceive coastal Croatia as a desirable destination for the vacation was tested with chi-square test. The chi-square test was used to determine is there dependence between previous touristic stay in Croatia and evaluation of available tourist resources in order to test the hypothesis. The chi-square test results are in the following two tables.

Table 2. Rating of Available Tourist Resources in Relation to Previous Stay in Croatia

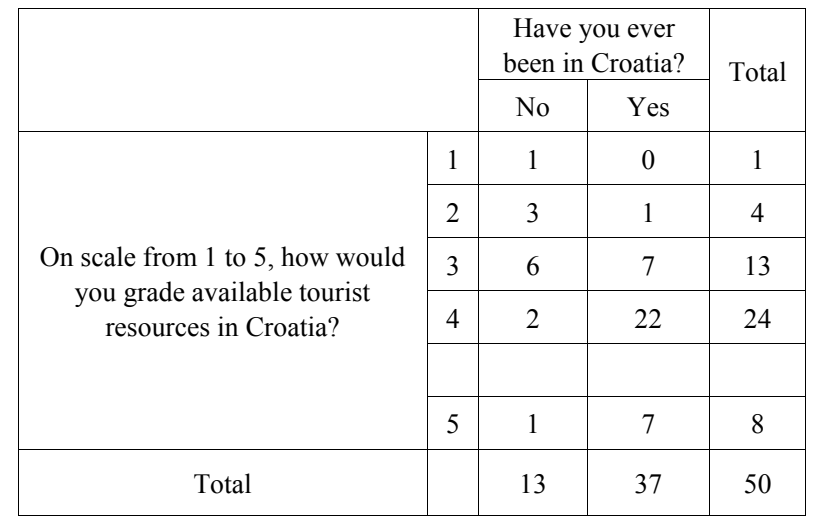


Table 3. Chi-square Test Results Tourist Resources and Previous Stay in Croatia

\begin{tabular}{|c|c|c|c|}
\hline & Value & Df & Asymp.Sig. (2- sided) \\
\hline Pearson Chi-Square & $15,233^{\text {a }}$ & 4 &, 004 \\
\hline Likelihood Ratio & 15,066 & 4 &, 005 \\
\hline McNemar-Bowker Test & & & b \\
\hline N of Valid Cases & 50 & & \\
\hline
\end{tabular}

6 cells $(60,0 \%)$ have expected count less than 5 . The minimum expected count is ,26. Computed only for a PxP table, where $\mathrm{P}$ must be greater than 1 . Having in mind fact chi-square $\left(\chi^{2^{*}}\right)$ is 15,996 , with 4 degrees of freedom $(\mathrm{df}=4)$ table value of chi-square $\left(\chi^{2} \mathrm{tab}\right)$ is 9,49 with the empirical significance of $5 \%$. Because of the fact $\chi \mathrm{c}^{\mathrm{c}^{*}}$ is higher than $\chi^{2}$ tab, and $\alpha$ is lower than $5 \%$ with the significance of $5 \%$, the assumption there is no dependence between previous touristic stay in Croatia and evaluation of available tourist resources is rejected. Another test for H1 hypothesis was dependence of Croatia as desirable destination and previous visits. The results are in following two tables.

Table 4. Croatia as Desirable Destination and Previous Visits

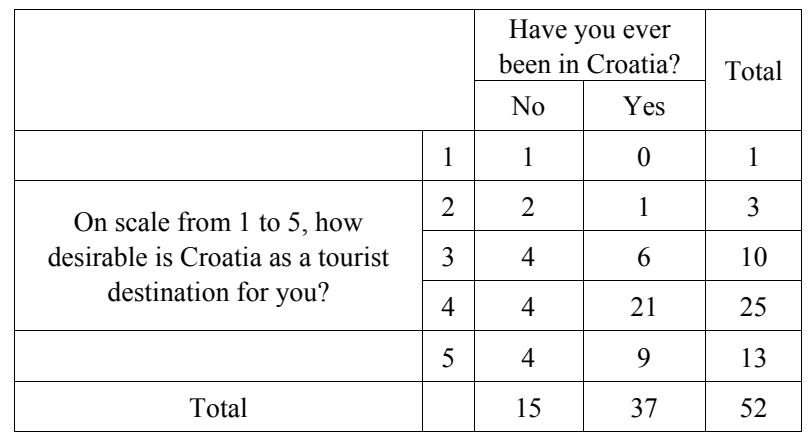

Table 5. Chi-square Test Results - Croatia as Desirable Destination and Previous Visits

\begin{tabular}{|c|c|c|c|}
\hline & Value & Df & Asymp.Sig. (2- sided) \\
\hline Pearson Chi-Square & $7,197^{\mathrm{a}}$ & 4 &, 126 \\
\hline Likelihood Ratio & 7,169 & 4 &, 127 \\
\hline McNemar-Bowker Test & & & $\mathrm{b}$ \\
\hline N of Valid Cases & 52 & & \\
\hline
\end{tabular}

6 cells $(60,0 \%)$ have expected count less than 5 . The minimum expected count is ,29. Computed only for a PxP table, where $P$ must be greater than 1 . Given the fact $\left(\chi^{2 *}\right)$ is 7,197 , with 4 degrees of freedom $(\mathrm{df}=4)$ table value $\left(\chi^{2}\right.$ tab) is 9,49 with the empirical significance of $5 \%$. Because of the fact $\chi \mathrm{c}^{2 *}$ is lower than $\chi^{2} \mathrm{tab}$, and the fact $\alpha$ is higher than $5 \%$ with the significance of $5 \%$, the assumption there is no dependence between previous tourist stay and Croatia as a desirable destination is accepted.

Respondents perceive in a positive way available resources of coastal Croatia and hypothesis $\mathrm{H} 1$ is rejected. Both chi-square tests show a positive connection between the previous stay in Croatia and positive opinion on available touristic resources as well as the fact Croatia is desirable destination no matter respondent visited it or not.

Hypothesis H2 - Existing tourism offer in coastal Croatia is not differentiated enough and inferiorly positioned on Swedish emissive market was tested with chi-square test. The chi-square test tested the dependence between accommodation mention in adverts related to Croatia and influence of advertising on search and finding of appropriate accommodation. Test results are in following two tables.

Table 6. Dependence of Advertising and Accommodation Search

\begin{tabular}{|c|c|c|c|c|c|c|c|}
\hline & & \multicolumn{5}{|c|}{$\begin{array}{l}\text { Would you say that advertising and promotional tools have influence on } \\
\text { you when you search \& choose appropriate accommodation in Croatia? }\end{array}$} & \multirow[t]{2}{*}{ Total } \\
\hline & & & I don`t know & Maybe & No & Yes & \\
\hline \multirow{4}{*}{$\begin{array}{l}\text { Was there any mention of } \\
\text { accommodation in Croatia in any of } \\
\text { previously mentioned resources? }\end{array}$} & & 3 & 0 & 0 & 0 & 0 & 3 \\
\hline & $\begin{array}{l}\text { I don`t } \\
\text { know }\end{array}$ & 0 & 2 & 6 & 5 & 10 & 23 \\
\hline & No & 0 & 0 & 5 & 5 & 3 & 13 \\
\hline & Yes & 0 & 0 & 4 & 1 & 11 & 16 \\
\hline Total & & 3 & 2 & 15 & 11 & 24 & 55 \\
\hline
\end{tabular}

Table 7. Chi-square Test Results - Dependence of Advertising and Accommodation Search

\begin{tabular}{|c|c|c|c|}
\hline & Value & Df & Asymp.Sig. (2- sided) \\
\hline Pearson Chi-Square & $65,483 \mathrm{a}$ & 12 &, 000 \\
\hline Likelihood Ratio & 34,301 & 12 &, 001 \\
\hline McNemar-Bowker Test &. &. &. $\mathrm{b}$ \\
\hline N of Valid Cases & 55 & & \\
\hline
\end{tabular}


16 cells $(80,0 \%)$ have expected count less than 5 . The minimum expected count is, 11 . Computed only for a PxP table, where $\mathrm{P}$ must be greater than 1 . Given the fact $\chi^{2 *}$ is 65,483 , with 12 degrees of freedom $(\mathrm{df}=12)$ table value $\left(\chi^{2} \mathrm{tab}\right)$ is 21,03 with the empirical level of significance of $5 \%$. Because the fact $\chi \mathrm{c}^{2^{*}}$ is higher than $\chi^{2}$ tab, and $\alpha$ is lower than $5 \%$ with the significance of $5 \%$, the assumption there is no dependence between stating accommodation in adverts related to Croatia and influence of advertising on search and finding of appropriate accommodation is accepted. Claim there is no dependence between stating accommodation in adverts related to Croatia and influence of advertising on search and finding of appropriate accommodation can be accepted. However, given the fact that 16 fields of the table have $80,0 \%$ of the value of expected frequencies is lower than 5 , and minimal expected value is 0,11 ; the test is not reliable and needs to be taken with hold back. Chi-square test showed there is no dependence between information related to accommodation in Croatia and influence of advertising on the search for appropriate accommodation. Based on this it can be concluded that available tourist resources are insufficiently implemented in the promotion of tourism offer and hypothesis $\mathrm{H} 2$ is accepted.

Following Chi-square tests tested hypothesis H3 Specialization in managing tourism promotion for emissive Swedish market does not contribute to the higher perceived value of the offer. First test tested the dependence between previous touristic stay in Croatia and evaluation of general tourism offer. The results are in following two tables.

Table 8. Dependence of Previous Visits and Opinion on General Tourist Offer

\begin{tabular}{|c|c|c|c|c|c|c|c|}
\hline \multicolumn{2}{|c|}{} & \multicolumn{5}{|c|}{$\begin{array}{c}\text { How would you grade general } \\
\text { offer of accommodation in }\end{array}$} & \multirow{2}{*}{ Total } \\
\cline { 3 - 8 } \multicolumn{2}{|c|}{} & 1 & 2 & 3 & 4 & 5 & \\
\hline $\begin{array}{c}\text { Have you ever } \\
\text { been in } \\
\text { Croatia? }\end{array}$ & No & 1 & 0 & 6 & 3 & 0 & 10 \\
\cline { 2 - 8 } & Yes & 0 & 1 & 12 & 21 & 3 & 37 \\
\hline Total & & 1 & 1 & 18 & 24 & 3 & 47 \\
\hline
\end{tabular}

Table 9. Chi-square Test Results - Dependence of Previous Visits and General Tourist Offer

\begin{tabular}{|c|c|c|c|}
\hline & Value & Df & Asymp.Sig. (2- sided) \\
\hline Pearson Chi-Square & $7,447 \mathrm{a}$ & 4 &, 114 \\
\hline Likelihood Ratio & 7,655 & 4 &, 105 \\
\hline McNemar-Bowker Test & & & $\mathrm{b}$ \\
\hline N of Valid Cases & 47 & & \\
\hline
\end{tabular}

7 cells $(70.0 \%)$ have expected count less than 5 . The minimum expected count is ,21. Computed only for a PxP table, where P must be greater than 1 .

Based on performed tests it can be concluded that available touristic resources in coastal Croatia are insufficiently implemented in promoting tourism offer. $\chi^{2^{*}}$ is 7,447 , with 4 degrees of freedom $(\mathrm{df}=4)$ table value $\left(\chi^{2}\right.$ tab) is 9,49 with the empirical level of significance of $5 \%$. Because of the fact $\chi \mathrm{c} 2 *$ is lower than $\chi^{2}$ tab, and $\alpha$ is higher of $5 \%$ with the significance of $5 \%$, the assumption there is dependence between previous touristic stay in Croatia and evaluation of general tourism offer in Croatia can be accepted. Respectively, there is dependence between previous touristic stay in Croatia and evaluation of general tourism offer in Croatia. General tourism offer in coastal Croatia is on enough high level and adapted to standards of Swedish emissive market. With analyzing answers in conducted surveys and half structured interview, it can be concluded that proactive managing of promotional mix of tourism organizations in coastal Croatia does not encourage additional interest for the yearlong visit from emissive Swedish market. To change this, it is crucial to implement integrated offer of activities and content on the destination level.

Another test tested dependence between previous touristic stay and noticing advertising material on tourist destination. Test results are in following two tables.

Table 10. Dependence of Previous Visits and Available Advertising Material about Croatian Tourist Offer

\begin{tabular}{|c|c|c|c|c|c|c|c|}
\hline \multicolumn{2}{|c|}{} & \multicolumn{5}{|c|}{$\begin{array}{c}\text { Have you ever noticed any } \\
\text { advertising material related to small } \\
\text { family owned hotels in Croatia? }\end{array}$} & \multirow{2}{*}{ Total } \\
\cline { 2 - 7 } \multicolumn{2}{|c|}{} & & $\begin{array}{c}\text { I don`t } \\
\text { know }\end{array}$ & Maybe & No & Yes & \\
\hline $\begin{array}{c}\text { Have } \\
\text { you ever } \\
\text { been in } \\
\text { Croatia? }\end{array}$ & No & 7 & 0 & 1 & 7 & 0 & 15 \\
\hline & Yes & 12 & 4 & 6 & 10 & 5 & 37 \\
\hline Total & & 22 & 4 & 7 & 17 & 5 & 55 \\
\hline
\end{tabular}

Table 11. Chi-square Test Results - Dependence of Previous Visits and Advertising Material on Tourism Offer

\begin{tabular}{|c|c|c|c|}
\hline & Value & Df & Asymp. Sig. (2- sided) \\
\hline Pearson Chi-Square & $11,256 \mathrm{a}$ & 8 &, 188 \\
\hline Likelihood Ratio & 14,455 & 8 &, 071 \\
\hline McNemar-Bowker Test & & & $\mathrm{b}$ \\
\hline N of Valid Cases & 55 & & \\
\hline
\end{tabular}

12 cells $(80.0 \%)$ have expected count less than 5 . The minimum expected count is ,22. Computed only for a PxP table, where $\mathrm{P}$ must be greater than 1 .

Given the fact $\chi^{2^{*}}$ is 11,256 , with 8 degrees of freedom $(\mathrm{df}=8)$ table value $\left(\chi^{2} \mathrm{tab}\right)$ is 15.51 with the empirical significance of $5 \%$. Because of the fact $\chi \mathrm{c}^{2^{*}}$ is lower than $\chi^{2}$ tab, and $\alpha$ is higher than $5 \%$ with the significance of $5 \%$, the assumption there is dependence between previous touristic stay and noticing advertising material of tourism destination is accepted. Therefore, it can be concluded that there is dependence between previous touristic stay and noticing advertising material of tourism destination. However, given the fact that 12 fields of the table have $80.0 \%$ of the value of expected frequencies is lower than 5 , and minimal expected value is 0.22 ; the test is not reliable and 
needs to be taken with hold back.

With previous chi-square tests, it is proved there is dependence between the previous stay in Croatia and evaluation of general tourism offer as well as there is dependence between previous touristic stay and noticing advertising materials on destination offer. It can also be concluded that promotional mix of the tourism offer is attractive to Swedish tourists who never been to Croatia. Promotion with personalized values of targeted Swedish emissive market is assumption of growth of interest tourist visits. With these tests we can conclude hypothesis H3 is rejected.

Research results lead to conclusion that promotion with personalized values of targeted Swedish emissive market is the assumption of growth of interest in the tourism destination. Based on conducted research and testing collected data it is noticeable that tourists from Sweden find Croatia as desirable destination. In the case of tourists from Sweden there is no dependence between previous tourist stay and evaluation of desirableness of Croatia as tourist destinations. Based on stated findings it can be concluded that available touristic resources in the seaside area of Croatia are attractive to Swedish emissive market and $\mathrm{H} 1$ hypothesis is rejected. Research results show that average promotion of touristic offer of Croatia is visible on Swedish emissive market, due to the fact almost $80 \%$ of respondents noticed adverts, primary in online media and public transportation adverts. H2 hypothesis accepted as test showed available tourist resources should be additionally presented in the promotion of tourist offer. On other hand, the available offer in coastal Croatia is sufficiently differentiated and positioned on the Swedish emissive market. It is interesting to highlight answers on the question "what would you like to have in the basic offer of tourism destination?" and respondents' answers were: a la carte restaurant with more choice of menus and employees that speak Swedish. Respondents highlighted the need for a higher number of offered activities and more entertainment content. When $\mathrm{H} 3$ hypothesis was tested, chi-square tests showed the dependence between the previous stay in Croatia and evaluation of general tourism offer. Research showed that the promotional mix of tourism offer in coastal Croatia is sufficiently differentiated to attract Swedish tourists who never been to Croatia. With these results $\mathrm{H} 3$ hypothesis is rejected.

\section{Conclusions}

Research results showed Croatia is perceived as desirable destination and that its tourist resources in seaside Croatia (Hotels, Hostels, B\&B, Apartments, Camping, Restaurants, Resorts, Amusement parks, Cafés, Lounge bars, Bars, Discos and other resources) are attractive to Swedish emissive market. The available resources of coastal Croatia are sufficient for developing specialized touristic products and services. Research showed that previous visitors and future visitors have positive opinion on general tourism offer and Croatia as destination in general. In same time research showed there is space for improvement when it comes to presenting available tourist resources in promoting Croatia as well as more activities in the destination. Even though that coastal Croatia has enormous potential and attractive tourist resources, Croatia is still perceived as a desirable tourist destination only during the summer. To change this image of Croatia as the summer-only destination, efforts in specialization on the individual or small entrepreneur level do not contribute a lot. One of the things to do is to expand content and tourism offer on destination level to achieve yearlong interest for incoming tourism. Additionally, if tourism offer is adapted to trends on Swedish emissive market it will encourage a visitor to choose same receptive business in the destination. When it comes to presenting available tourist resources and choosing appropriate promotional mix, one of the first things to do is to implement personalized values of Swedish emissive market. With this the interest in Croatia as destination has the potential to additionally expand. Swedish emissive market is unique for many reasons and one of them is their search for diversity when it comes to offering and content of destination. The efficiency of managing tourism promotion is the key to the growth of arrival of Swedish tourists. Some of the elements of promotional mix have higher influence on customer and they should be used more frequently. The perfect example is elements of the promotional mix which allow materialization of the offer in the perception of the targeted visitor - for example multimedia content in advertising. Research of this paper confirmed the influence of positive experiences from previous guests and their ability to notice advertising. Improving the elements of promotional mix should be based on information collected from loyal and previous guests' opinion. This means the collected information should be used when adverts and social media campaigns are created and then launched on the emissive market. Even though Swedish emissive market does not have a big population; this market has high buyer power and showed interest in traveling outside the main touristic season but chooses destinations with various and interesting activities. Adaptivity and flexibility of tourism offer to trends of the emissive market is the precondition to be chosen as an attractive destination. Price of the offer needs to be looked in the context of perceived value for money which means that every additional activity can be charged at the integrated price. In same time if a tourism organization offers premium service to Swedish customer, they can offer it at premium price. In managing tourism promotion in order to attract Swedish tourists it is not necessary to invest in standardized and expensive means of promotion (fairs, adverts in tourist catalogues and TV advertising). Swedish emissive market primary values word of mouth and recommendation which means that the 
base of future promotion is the satisfaction of present customer and visitor. This with online promotion has significantly higher influence in comparison to classic promotion methods. Online media, with emphasis on social networks, should represent the basic platform of tourism promotion for the destination which aims to target Swedish emissive market. Along with that, it is crucial to implement online booking systems in business processes due to the fact Swedish tourists prefer this way of booking. Finally, it is important to distribute destination offer on Swedish emissive market with distribution channels of specialized tourist agencies and tour operators in order to ensure loyal clientele and increase in sales. With all these efforts Croatia as destination should be positioned as highly attractive for Swedish emissive market and previous and future customers. In this way, destination will have set marketing goals and strategies and in same time customer can have great experiences and higher value for money.

\section{REFERENCES}

[1] Morrison, A. M., Marketing and Managing Tourism Destinations, Routledge, London, 2013.

[2] Hedlund T., Marell A., Gärling T., The mediating effect of value orientation on the relationship between socio-demographic factors and environmental concern in Swedish tourists' vacation choices, Journal of Ecotourism, 11(1), pp.16-33, 2012.

[3] Prebensen N., Skallerud K., Chen J.S., Tourist Motivation with Sun and Sand Destinations: Satisfaction and the Wom-Effect, Journal of Travel \& Tourism Marketing, 27:8 pp. 858. - 873, 2010.

[4] Pike, S., Destination marketing: an integrated marketing communication approach, Elsevier, Oxford UK, 2008.

[5] Šerić, N., Jurišić, M., Methodological approach and model analysis for identification of tourist trends, Journal of Economics and Business, EFIS n. 10/2015, pp. 47 - 54, 2015.

[6] Tribe, J. The Economics of Recreation, Leisure and Tourism, Elsevier Ltd. London UK, 2012.

[7] Sharpley, R., Host perceptions of tourism: A review of the research, Tourism Management, Vol. 42, pp. 37-49, 2014.

[8] Raju, G.P., Tourism marketing and management, Manglam publications, Delhi, India, 2009.

[9] Moriarty S., Mitchell N., Wells W., Advertising \& IMC, Principles \& Practice, 9th edition, Prentice Hall, 2012.

[10] Candela, G., Figini, P. The Economics of Tourism Destination, McGraw-Hill Companies Inc. Publishing Italia, 2010.

[11] Butler, R.W., The tourism area life cycle vol.1, Cromwell Press, UK, 2006.

[12] Raaij, E. M., Stoelhorst, J.W., The Implementation of a
Market Orientation: A Review and Integration of the Contributions to Date, European Journal of Marketing, Vol. 42, pp. 1265-1293, 2008.

[13] Sharpley, R., Host perceptions of tourism: A review of the research, Tourism Management, Vol. 42, pp. 37-49, 2014.

[14] Šerić M., Gil-Saura I., Mollá-Descals A., Loyalty in High-Quality Hotels of Croatia: From Marketing Initiatives to Customer Brand Loyalty Creation, Journal of RelationshipMarketing, 12:2, pp. 114-140, 2013.

[15] Conrady, R., Buck, M., Trends and Issues in Global Tourism 2011, Springer, Berlin Heidelberg, Germany, 2011.

[16] Baxter, J., Kerr, G., The meaning and measurement of place identity and place image, School of Management and Marketing, Faculty of Commerce, University of Wollongong, Australia, NSW, 2010.

[17] Hall, D.R., Smith, M.K., Marciszewska, European Tourism Planning and Organization Systems, Elsevier UK, 2012.

[18] Middleton T.C.V., Fyall A., Morgan M., Morgan M., Ranchhod A., Marketing in Travel and Tourism, Routledge, 2009.

[19] The Nordic Outbound Travel Market, Online available from https://slidex.tips/download/the-nordic-outbound-travel-ma rket-5

[20] The World Bank, Data, International tourism, expenditures, O nline available from https://data.worldbank.org/indicator/ ST.INT.XPND.CD

[21] Chamber Trade Sweden, Outbound Tourism, Online a vailable fromhttp://chambertradesweden.se/wp-content/up loads/2012/12/Tourism_EU_may2011.pdf 